UDC 347.918 .2

Submitted: 13.01 .2021

LBC 67.410 .14

Accepted: 04.02.2021

\title{
THE EXTENSION OF THE ARBITRATION CLAUSE TO NON-SIGNATORIES: LESSONS FROM COMPARATIVE LAW ${ }^{1}$
}

\author{
Ekaterina P. Rusakova \\ Peoples' Friendship University of Russia, Moscow, Russian Federation \\ Edgar J. Young Dominguez \\ Peoples' Friendship University of Russia, Moscow, Russian Federation
}

Introduction: is it possible for a legal entity or individual who has not signed a contract containing the arbitration clause to take precedence of initiating arbitration against the signatory legal entity or individual, or vice versa, to be involved in the legal proceedings by other persons? The paper discusses this issue and examines it from the point of view of several theories, within the framework of comparative law, accepted for the extension of the arbitration clause to non-signatories. The purpose of the research is achieved by solving a number of tasks: to identify recurrent cases when an arbitration agreement was extended to a party that did not formally sign any arbitration agreement; to analyze the scenarios where such extension was accepted in different jurisdictions, as well as the facts and legal basis for this. Methodology: the paper uses a comparative method of analyzing the legal framework and court decisions, and the arbitral awards from different jurisdictions allow us to understand the degree of acceptability of the theories related to the extension of the arbitration clause to non-signatories. The results of the research can be used to determine the key circumstances of arbitration - whether the non-signatory party can be included in the arbitration either being initiated or already commenced. Conclusions: although there are various legal theories that have created a number of possibilities for extending the arbitration clause, such theories have a greater or lesser degree of acceptance depending on the arbitration law adopted by each country, the agreement of the parties, the arbitration rules chosen by the parties, the applicable law to the contract and, in some cases, the arbitration law at the legal venue. In addition, it will be necessary to analyze whether the non-signatory party is actually a party to the arbitration agreement, the relationship on the merits of the dispute, the interest and participation in the performance of the contract, and the application of the principle of good faith.

Key words: agency agreement, arbitration clause, incorporation by reference, guarantees, mandate agreement, alter-ego doctrine, group of companies doctrine, the doctrine of piercing the corporate veil, international arbitration, acquiescence, non-signatories, representation, acceptance, extension, consent, third-party beneficiary, estoppel.

Citation. Rusakova E.P., Young Dominguez E.J. The Extension of the Arbitration Clause to Non-Signatories: Lessons from Comparative Law. Legal Concept = Pravovaya paradigma, 2021, vol. 20, no. 1, pp. 144-154. (in Russian). DOI: https://doi.org/10.15688/lc.jvolsu.2021.1.22

\section{РАСПРОСТРАНЕНИЕ АРБИТРАЖНОЙ ОГОВОРКИ НА НЕ ПОДПИСАВШИЕ ЕЕ СТОРОНЫ: УРОКИ СРАВНИТЕЛЬНОГО ПРАВА ${ }^{1}$}

\author{
Екатерина Петровна Русакова
}

Российский университет дружбы народов, г. Москва, Российская Федерация

\author{
Эдгар Хосуэ Йонг Домингес
}

Российский университет дружбы народов, г. Москва, Российская Федерация 
Введение: возможно ли, чтобы юридическое или физическое лицо, не подписавшее договор, содержащий арбитражную оговорку, имело преимущественное право на инициирование арбитража против подписавшего его юридического или физического лица, или наоборот было привлечено к судебному разбирательству другими лицами? Настоящая статья посвящена данному вопросу и рассматривает его с точки зрения нескольких теорий, в рамках сравнительного права, принятых для распространения арбитражной оговорки на не подписавшие ее стороны. Цель настоящего исследования достигается путем решения ряда задач: выявить повторяющиеся случаи, когда арбитражное соглашение было распространено на сторону, которая с формальной точки зрения не подписала никакого арбитражного соглашения; проанализировать сценарии, когда такое распространение было принято в различных юрисдикциях, а также факты и правовую базу для этого. Методология: в настоящей статье применяется сравнительный метод анализа нормативно-правовой базы и судебных решений, а арбитражные решения различных юрисдикций позволяют понять степень приемлемости теорий, связанных с распространением действия арбитражной оговорки на не подписавшие ее стороны. Результаты исследования могут быть использованы для определения ключевых обстоятельств арбитражного разбирательства - может ли не подписавшая ее сторона быть включена в инициируемый или уже начавшийся арбитраж. Выводы: несмотря на то, что существуют различные правовые теории, создавшие целый ряд возможностей для расширения арбитражной оговорки, такие теории имеют большую или меньшую степень признания в зависимости от законодательства об арбитраже, принятого каждой страной, соглашения сторон, выбранного сторонами арбитражного регламента, применимого права к договору и, в некоторых случаях, законодательства об арбитраже в месте рассмотрения спора. Кроме того, потребуется провести анализ того, действительно ли сторона, не подписавшая арбитражное соглашение, является стороной арбитражного соглашения, о связи по существу спора, об интересе и участии в исполнении договора и о применении принципа добросовестности.

Ключевые слова: агентский договор, арбитражная оговорка, включение путем ссылки, гарантии, договор поручения, доктрина «альтер-эго», доктрина «группы компаний», доктрина «снятия корпоративной вуали», международный арбитраж, молчаливое согласие, не подписавшие стороны, представительство, принятие, распространение, согласие, сторонний бенефициар, эстоппель.

Цитирование. Русакова Е. П., Йонг Домингес Э. Х. Распространение арбитражной оговорки на не подписавшие ее стороны: уроки сравнительного права // Legal Concept = Правовая парадигма. - 2021. - T. 20, № 1. -C. 144-154. - DOI: https://doi.org/10.15688/lc.jvolsu.2021.1.22

\section{Введение}

Большинство коммерческих операций и сделок представляют собой сложную сеть из нескольких сторон и контрактов. В настоящее время сложность контрактов возросла в результате сложных коммерческих сделок, во многих случаях связанных с множественностью сторон, контрактов, субподрядов, уступок, что приводит к столь же сложным арбитражным разбирательствам. Часто стороны варьируются при ведении переговоров, подписании контракта или выполнении проекта. Сторона, участвующая в переговорах по контракту, не обязательно должна участвовать в его исполнении. Возможно, что сторона, участвующая в исполнении договора или его части, не является формальной (подписавшей) стороной договора, и по данной причине требования о правах и обязательствах должны быть предъявлены через них. Это могут быть случаи, когда сторона, уча- ствующая в договоре, не обязательно является стороной, подписавшей договор, содержащий арбитражную оговорку, на которой основан арбитраж.

Согласие на арбитраж рассматривается в качестве непременного или sinequanon условия как в национальном, так и международном арбитраже. Поэтому привлечение сторон, не подписавших соглашение, к арбитражной процедуре по-прежнему является спорной, но интересной темой для анализа и обсуждения, имеющей значительную практическую ценность. Распространение действия арбитражной оговорки на сторону, не подписавшую соглашение или договор, влечет за собой логическое следствие - передачу спора в третейский суд, когда это прямо не предусмотрено, ставя под сомнение в некоторой степени основные принципы, на которых основывается арбитражное законодательство, такие как: принцип относительности договора и принцип автономии сторон. 


\section{МЕЖДУНАРОДНОЕ ПРАВО И СРАВНИТЕЛЬНОЕ ПРАВОВЕДЕНИЕ}

На практике объединение сторон, подписавших и неподписавших соглашение, в рамках одного арбитражного процесса обеспечивает более высокую скорость, меньшую стоимость и позволяет избежать принятия противоречивых и несправедливых решений. Такое объединение или консолидация корпорации или физического лица в арбитражном процессе не меняет правовой природы процедуры, оно просто укрупняет истца или ответчика, что может быть полезно с точки зрения стратегии. В качестве наступательной стратегии истец может пожелать привлечь достаточные средства для обеспечения исполнения арбитражного решения путем добавления к процедуре материнской компании ответчика. В качестве защитной стратегии ответчик может захотеть воспользоваться арбитражной оговоркой, чтобы избежать судебного разбирательства в суде присяжных.

\section{1. Молчаливое согласие или принятие}

При анализе молчаливого согласия арбитры должны постоянно наблюдать за действиями сторон: в ходе переговоров, заключения, исполнения и расторжения договора. Это может дать некоторое представление о сфере охвата, актуальности и участии не подписавшего арбитражное соглашение лица, а также о том, может ли оно рассматриваться в качестве стороны арбитражного соглашения. Молчаливое согласие может вытекать из участия не подписавших сторон в основной правовой деятельности и осведомленности о существовании арбитражного соглашения.

В отличие от других правовых систем, французские суды положительно относятся к распространению арбитражной оговорки на не подписавшие ее стороны, как это видно в следующих случаях: Amkor, Suba France и Kosa France.

В деле Alcatel Business System (ABS) v. Amkor [3] Французский кассационный суд постановил, что арбитражное соглашение может быть распространено на одну из дочерних компаний, основываясь на ее поведении и участии, для включения в арбитражное разбирательство, и что Amkor не может оспаривать компетенцию арбитражного суда, ссылаясь на неосведомленность о существовании арбитражного соглашения.

В деле Suba France v. Pujol [32] Апелляционный суд Парижа постановил, что решение арбитров распространить действие арбитражного соглашения на компанию Suba \& Unico было действительным до тех пор, пока она принимала непосредственное участие в исполнении контракта, содержавшегося в соглашении; он также определил, что арбитражная оговорка, содержащаяся в международном договоре, обладая собственной действенностью и эффективностью, должна быть распространена на стороны, непосредственно вовлеченные в исполнение договора, и соответственно должна быть связана с дальнейшим результатом арбитражного решения.

В деле Kosa France [27, p. 580] Апелляционный суд Парижа подтвердил данные прецеденты в том смысле, что признание арбитражной оговорки наряду с активной ролью в исполнении договора равносильно молчаливому согласию или принятию от не подписавшей его стороны.

В деле Mécaniques de Normandie [30, p. 1098] Кассационный суд Франции постановил, что «действия международной арбитражной оговорки распространяется на подрядчика, который был осведомлен о ее существовании, когда заключил собственный контракт и непосредственно участвовал в исполнении основного контракта», и «международная арбитражная оговорка между заказчиком и подрядчиком распространяется и на субподрядчика, знавшего о ее существовании, при заключении собственного контракта без необходимости ее особого принятия с его стороны».

Тем не менее подход европейских судов к определению достаточной степени участия компаний в рамках молчаливого согласия не подписавших сторон может быть различным. Это прекрасно иллюстрируют диаметрально противоположные решения по делу Dallah Real Estateand Tourism в английских [10] и французских судах [14].

В Соединенных Штатах Америки суды и научные круги чаще используют термин «принятие» для обозначения «молчаливого согласия» в том смысле, что именно не подписавшая сторона принимает на себя обязательства подписавшей арбитражную оговорку стороны. 
Принятие как форма правового основания отражено в деле Thomson-CSF [36], где заявлялось, что в отсутствие подписи сторона может быть связана арбитражной оговоркой, если ее последующее поведение указывает на то, что она берет на себя обязательство об арбитраже. В этом смысле американские суды также принимают во внимание поведение стороны, просто в более широком или общем плане, если сравнивать с подходом Международной торговой палаты (МТП).

\section{2. Доктрина «группы компаний»}

Доктрина «группы компаний» была принята лишь некоторыми европейскими юрисдикциями для подтверждения согласия не подписавшей третьей стороны на арбитражную оговорку и установления ответственности, когда коммерческие операции не подписавшей третьей стороны и подписавшей стороны тесно взаимосвязаны. Это означает, что два юридических лица, даже если они формально разделены, могут рассматриваться как единое целое, поскольку они ведут коммерческие операции таким тесным образом, что одно из них осуществляет контроль над другим.

Доктрина «группы компаний» зародилась во Франции в 1987 г. благодаря делу Dow Chemical v. Isover Saint Gobain, ставшему одним из первых знаковых и спорных случаев распространения арбитражной оговорки в международном коммерческом арбитраже.

В данном случае Dow Chemical Co. ocyществляла прямой контроль над своими дочерними компаниями, с тем чтобы материнская компания была эффективно вовлечена в переговоры, исполнение и расторжение контракта. Сторона продавцов не придавала существенного значения тому, с какой компанией из группы Dow Chemical они имеют дело, так как все компании попеременно участвовали в качестве группы для распределения продуктов во Франции. Суд определил, что компании Dow Chemical были частью одной экономической реальности и действовали при заключении и исполнении контракта как группа, поэтому их следует рассматривать как сторону арбитражного соглашения.

Арбитражным судом в данном случае установлено, что, хотя каждая компания в группе обладает своей правосубъектностью, «арбитражная оговорка, прямо принятая некоторыми компаниями группы компаний, должна считаться обязательной для других компаний с учетом их роли в заключении, исполнении или расторжении контрактов, содержащих такие оговорки, и в соответствии с общим намерением сторон участвовать в арбитражном проиессе, являясь действительными сторонами или главным образом связанными с контрактами и спорами, вытекающими из них» [17, p. 464].

Во Франции доктрина «группы компаний» с тех пор настолько широко распространилась, что Апелляционный суд определил ее как «признанный закон» в деле Société Sponsor A.B. v. Ferdinand Louis Lestrade [29, 153].

Верховный суд Испании использовал данную доктрину в деле ITSA v. Satcan \& $B B V A$ [19]. Наконец, Федеральный суд Швейцарии недавно «значительно смягчил свою судебную практику» по этому вопросу [15, p. 351].

Ряд решений МТП впоследствии поддержал данную позицию, например, решения МТП № 5103, 5721, 7604, 7610, 8385, 9517, 9719 и 11209.

Тем не менее данная доктрина не была полностью признана некоторыми правовыми системами, такими как Швейцария, Нидерланды и Германия, из-за их традиционного конституционного и процессуального законодательства. Гражданские суды признали критические замечания, но сочли себя не вправе принимать данную доктрину из-за конституционных и процессуальных препятствий $[16$, p. 11]. Швейцария, в частности, не приняла доктрину «группы компаний», однако швейцарские суды разрешили распространение оговорки на не подписавших ее лиц на основании фактического анализа дела и активного участия компании в исполнении контракта.

В США доктрина «группы компаний» имеет ограничительный подход. В деле Sarhank Group v. Oracle Corporation [38] третейский суд применил доктрину «группы компаний», заявив, что «хотя дочерние компании одной группы компаний представляют собой отдельные юридические лица, они считаются участниками арбитражной оговорки, включенной в любую сделку, либо являются 
ее сторонами по условиям договора, поскольку договорные отношения не могут иметь место без согласия материнской компании, владеющей товарным знаком и осуществляющей сделки». Окружной суд счел обязательным для себя данное постановление, однако апелляционный суд отменил данное решение на основании соображений публичного порядка и не допустил потенциального распространения данной доктрины.

Несмотря на интересные юридические дебаты в течение последних десятилетий, английские суды также имеют в целом ограничительный подход, когда речь заходит о принятии доктрины «группы компаний». В деле Peterson FarmsInc v. C\& M Farming [23] Высокий суд отклонил доктрину «группы компаний», заявив, что выявление сторон соглашения является вопросом материального, а не процессуального права и что «доктрина «группы компаний» не является частью английского права», предполагая ограничительный подход в этом вопросе. Внимательный анализ этого дела может свидетельствовать о том, что его аргументация в большей степени основывается на цели «отрицания косвенного ущерба», чем на доктрине «группы компаний» [22, p. 581].

В деле Roussel-Uclaf v. Searle [26, 225] английские суды приняли эту доктрину на основе «здравого смысла». В данном случае истец подал иск не только против материнской компании, подписавшей лицензионное соглашение с компанией Searle, имеющее арбитражную оговорку, но и против дочерней компании. Высокий Суд Англии постановил, что дочерняя компания, претендующая на получение выгоды от арбитражного соглашения, стороной которого она не является, имеет право на приостановление судебного разбирательства в пользу арбитража. Однако в 2008 г. по делу Cityof London v. Sancheti [8] английский Апелляционный суд отменил решение Roussel-Uclaf v. Searle, вновь подтвердив свой ограничительный подход.

\section{3. Представительство, агентский договор или договор поручения}

Представительство, агентский договор или договор поручения в качестве теории для распространения арбитражной оговорки на не подписавшие ее стороны значительно укрепились в Европе. В основе данной теории лежит договор поручения, согласно которому одна его сторона берет на себя обязательство перед другой стороной подписать от имени последней договор, содержащий арбитражную оговорку. Третейские суды сочли, что агент не является связанной стороной в рамках договора, поскольку юридическую ответственность несет не подписавшая сторона. Основополагающий момент здесь заключается в отношениях поручения между подписавшей и не подписавшей сторонами, которые могут возникнуть с помощью или без представительства, но из чего следует, что в связи с участием подписанта не подписавшая соглашение сторона становится истинной заинтересованной стороной в рамках правовых и экономических отношений и, следовательно, в конечном результате арбитражного решения.

В Соединенных Штатах в деле Thomson$C S F$ [36] Второй окружной суд отметил, что в соответствии с Федеральным законом об арбитраже он неизменно заявлял, что не подписавшая сторона может быть связана арбитражным соглашением в соответствии с общими принципами договорного права и что «общие принципы агентского права могут связать не подписавшую сторону арбитражным соглашением».

Ведутся споры о том, необходимо ли прямое разрешение со стороны принципала, где бы указывалось, что агент имеет право принять арбитражную оговорку. Такие споры не получили широкой поддержки, поскольку право, применимое к арбитражному соглашению, варьируется в зависимости от места его проведения, а также разнятся положения, касающиеся полномочий в рамках договора поручения и вытекающих из него. Например, швейцарское законодательство требует, чтобы принципал прямо устанавливал полномочия агента на подписание арбитражного соглашения от его имени; австрийское законодательство также требует, чтобы указанное разрешение было выдано в письменной форме. В то время как во Франции, Италии и Германии письменное разрешение не является обязательным по закону. 


\section{4. Доктрина «альтер-эго»} или «снятия корпоративной вуали»

Третейский суд вправе пренебречь отдельной и независимой правосубъектностью организации и распространить арбитражное соглашение на скрытых третьих лиц для предупреждения и/или предотвращения мошенничества, злоупотребления правом, независимо от того являются ли лица членами одной группы или нет, если одна организация осуществляет контроль над другой и использует ее как марионетку или подставную компанию [12, p. 160]. Именно такое злоупотребление позволяет сделать исключение из принципов разделения активов и того, что никто не несет обязательств без собственного согласия. Мошеннические организации могут рассматриваться как единое целое для защиты другой стороны от недобросовестности.

Французские и американские суды в нескольких случаях «сняли» или «прокололи корпоративную вуаль», наметив тенденцию принимать данную теорию. Несмотря на это, обе юрисдикции подчеркивали необходимость применения данной доктрины только в исключительных случаях, когда основополагающее единство интересов и права собственности является настолько очевидным, что подчиняет себе разделение юридических лиц в целях предотвращения мошенничества или несправедливости.

В Соединенных Штатах доктрина «альтер-эго» или «снятия корпоративной вуали» была признана в таких делах, как ThomsonCSF [36] и Rolls Royce [25, 879], показав, что в некоторых случаях корпоративные отношения между материнской и дочерней компаниями достаточно тесные, чтобы оправдать «прокалывание корпоративной вуали» и привлечение одной корпорации к юридической ответственности за действия другой. Данная позиция подтвердилась в деле Oriental Commercial [21], когда американский суд заявил, что «для применения доктрины «альтерэго», чтобы оправдать игнорирование корпоративного образования, суд должен определить, что существует такое единство интересов и собственности, что отдельные лица корпораций больше не существуют и что несоблюдение корпоративной формы приведет к мошенничеству или несправедливости».
Английские суды, с другой стороны, имели тенденцию избегать «снятия» или «прокалывания корпоративной вуали», если только корпоративная вуаль и самостоятельная правосубъектность не являются лишь обманом или фасадом, как было продемонстрировано в делах Woolfson [39], Adams v. Cape Industries [2] и Acatos [1]. В Швейцарии и Германии суды подходят к данному вопросу с осторожностью, поскольку он предполагает противоречие принципу самостоятельной правосубъектности, и пришли к выводу о необходимости применения данной доктрины лишь в исключительных обстоятельствах.

\section{5. Включение путем ссылки}

Ссылка в договоре на любой документ, содержащий арбитражную оговорку, представляет собой арбитражное соглашение в письменной форме, при условии, что ссылка такова, что делает эту оговорку частью договоpa [37]. Включение путем ссылки признается арбитражными судами в той мере, в какой она подразумевает, что две стороны заключили договор, ссылаясь на другой договор, содержащий арбитражную оговорку. Таким образом, если договор или документ, включенный посредством ссылки, содержит арбитражную оговорку, то он будет являться частью прав и обязанностей сторон. Согласно данной теории не подписавшей стороне разрешается обращаться в арбитраж против подписавшей соглашение стороны при условии, что обе стороны заключили договор, где упоминается и включается арбитражное соглашение. Как правило, для арбитров этого достаточно, когда ссылка на арбитражное соглашение является прямой, проблема же возникает, когда ссылка на документ не является прямой. Включение путем ссылки, как правило, применяется в строительных договорах и коносаментах, чтобы облегчить осуществление сделок или в тех случаях, когда имеется несколько договоров, но в конечном счете ссылка делается на договор, содержащий арбитражную оговорку, поэтому ссылка на такой договор охватывает арбитражную оговорку.

В прецедентном праве Соединенных Штатов это толковалось как случай, когда сторона, не подписавшая арбитражное соглаше- 
ние, заключила иной договор с одной из сторон, в соответствии с которым она «приняла на себя все обязательства и привилегии, вытекающие из арбитражного соглашения», или когда арбитражная оговорка прямо включена в коносамент, и в этом случае не подписавшие стороны, которые имеют отношение к последнему документу на основании общих принципов, могут быть юридически связаны с последним. В деле Thomson-CSF [36] было указано, что «не подписавший может потребовать провести арбитражное разбирательство против стороны арбитража, когда эта сторона вступила в отдельные договорные отношения с не подписавшим, которые включают существующую арбитражную оговорку».

Французская сторона придерживается весьма ограничительного подхода, требуя прямой ссылки, как видно из дела Bomar Oil N.VETAP [13], где указано, что Нью-Йоркская конвенция не исключает принятия арбитражной оговорки путем ссылки на отдельный документ. Однако, согласно французскому законодательству, наличие такой оговорки должно быть указано в договоре, если только стороны не поддерживают регулярные отношения, которые приводят к тому, что стороны полностью осведомлены обо всех условиях, регулирующих их предпринимательскую деятельность. В деле Psichikon [24] Кассационный суд Франции постановил, что простая ссылка в коносаменте на договор фрахтования, стороной которого не являлся судовладелец, не может служить основанием для установления того, что арбитражная оговорка была принята получателем. В деле Crouzier [7] было решено, что сам факт того, что арбитражная оговорка не упоминается в договоре, но есть простая ссылка на стандартные условия, не является достаточным для установления существования действительной арбитражной оговорки, и что прежде чем определять недостаточность необходимо понять, знала ли сторона, оспаривающая ссылку, о стандартных условиях, и если да, то признала ли она их своим молчанием.

Английские суды также, как правило, имеют ограничительный подход. Высокий суд Англии в деле Mc Alpine [4] постановил, что для достижения согласия по арбитражной оговорке, включенной в отдельный договор, эта оговорка должна быть прямо упомянута в документе, который ее включает. В деле $B e n$ Barret [5] тот же суд постановил, что арбитражное соглашение не было включено в условия договора, что если необходимо включить отдельный договор, то он должен быть прямо упомянут в документе, который рассматривается в качестве указывающего на включение текста. Включение невозможно посредством простой ссылки на условия договора, где арбитражная оговорка представляет собой отдельный договор.

С другой стороны, позиция Швейцарии является более либеральной в признании действительности общей ссылки, как, например, в деле Tradax v. Amoco case [34]. Кроме того, в деле Mediterranean Shipping [9] Федеральный суд Швейцарии счел, что в особых обстоятельствах данное поведение может, согласно принципам добросовестности, компенсировать отсутствие письменной формы.

\section{6. Эстоппель}

Суды США использовали термин «справедливый эстоппель» для охвата двух различных версий доктрины: первого и второго вариантов. Однако американские окружные суды не применяют данную теорию в единообразном порядке.

Первый вариант был применен в деле Int'l Paper Co. [18, 411], где указывалось, что «сторона может быть лишена права утверждать, что отсутствие ее подписи в договоре препятствует приведению в исполнение арбитражной оговорки по этому договору, когда она последовательно указывала, что другие положения того же договора должны быть соблюдены в ее пользу». В деле Bouriez v. Carnegie Mellon $[6,418]$ был сделан вывод о том, что «не подписавшие стороны могут быть справедливо отстранены от оспаривания соглашения, включающего арбитражную оговорку, когда они принимают соглашение и извлекают из него непосредственную выгоду».

Второй вариант справедливого эстоппеля используется для того, чтобы помешать подписавшим сторонам, которые пытаются обратиться в суд, отрицать существование арбитражной оговорки. Не подписавшая сторона не может быть лишена права отрицать 
существование такой оговорки. В деле $M S$ Dealer v. Franklin [20, 942] Суд одиннадцатого округа пояснил две ситуации, когда не подписавшая сторона может обязать подписавшую сторону обратиться в арбитраж. Во-первых, справедливый эстоппель применяется, когда сторона, подписавшая содержащее арбитражную оговорку письменное соглашение, должна полагаться на условия письменного соглашения в отстаивании своих претензий в отношении не подписавшей стороны. Во-вторых, применение справедливого эстоппеля оправдано, когда подписавший выдвигает обвинения относительно существенно взаимозависимых и согласованных неправомерных действий как со стороны, не подписавшей соглашение, так и с одной или более сторон, подписавших договор. Данное обоснование приводится в делах Sunkist [33, 753] и Smith/ Enron [28].

\section{7. Сторонний бенефициар}

Арбитражное соглашение может распространяться на сторонних бенефициаров. В прецедентах США и Великобритании указывается, что если третья сторона соглашается стать бенефициаром договора между другими сторонами, и этот договор содержит арбитражную оговорку, то эта третья сторона должна передать споры на такой арбитраж. Данная позиция была подтверждена в деле Tareau [35, 611].

Американские суды признали распространение арбитражной оговорки на сторонних бенефициаров, не подписавших договор. В деле Dement [11, 797] окружной суд США постановил, что «лицо может подать в суд в целях обеспечения выполнения договора, стороной которого оно не является, если оно докажет, что договаривающиеся стороны намеревались в первую очередь и непосредственно принести выгоду ему или категории лиц, к которой он относится». В деле Chartered Mutual [31, 635] американские суды постановили, что сторонний бенефициар связан положениями и условиями договора, на которые он пытается ссылаться, и что бенефициар не может извлекать преимущества и избегать обязанностей или ограничений по договору.

Английские суды распространили арбитражную оговорку, содержащуюся в договоре, на сторонних бенефициаров по существенным положениям договора, с тем чтобы третья сторона могла обеспечить соблюдение положений в отношении давшего обещание лица через арбитраж. Лицо, давшее обещание, может взаимно ссылаться на арбитражное соглашение для приостановления разбирательства, возбужденного против него в судах. С другой стороны, французские суды отказали в распространении арбитражной оговорки на стороннего бенефициара на том основании, что арбитражная оговорка может создавать только права, а не обязательства.

\section{Вывод}

Молчаливое согласие однозначно признано французскими судами с особым соблюдением степени участия той или иной стороны в ходе переговоров, заключения, исполнения и расторжения договора. Данный анализ помогает избежать несправедливого решения, основываясь на фактических аспектах и добросовестности между сторонами. Американские суды и ученые, с другой стороны, предпочитают термин «принятие» для обозначения «молчаливого согласия» в том смысле, что именно не подписавшая сторона принимает на себя обязательства подписавшей арбитражную оговорку стороны. Однако в Соединенном Королевстве используется диаметрально противоположный подход, поскольку английские суды не приняли данную теорию.

Доктрина «группы компаний» возникает на двойственной юридико-экономической основе с условием, что компания из группы компаний или холдинга отделена с юридической точки зрения от остальных компаний, но с экономической точки зрения они являются группой и действуют как группа, что предполагает контроль, руководство и управление со стороны материнской компании над ее дочерними компаниями, и в результате возникают отношения зависимости. Данная доктрина была принята лишь некоторыми европейскими юрисдикциями, как, например, Франция и Испания. Ряд решений МТП поддержал данную позицию, однако, данная доктрина не была полностью признана некоторыми правовыми системами, такими как Швейцария, Нидерланды и Германия, из-за их традиционного кон- 
ституционного и процессуального законодательства. Американские и английские суды имеют в целом ограничительный подход, когда речь заходит о принятии доктрины «группы компаний», о чем свидетельствуют их судебные решения.

Представительство, агентский договор или договор поручения в качестве теории для распространения арбитражной оговорки на не подписавшие ее стороны значительно укрепились Европе. В основе данной теории лежит договор поручения, согласно которому одна его сторона берет на себя обязательство перед другой стороной подписать от имени последней договор, содержащий арбитражную оговорку. Ведутся споры о том, необходимо ли прямое разрешение со стороны принципала, где бы указывалось, что агент имеет право принять арбитражную оговорку. Результаты разнятся в зависимости применимого к арбитражному соглашению права. Швейцарское законодательство требует, чтобы принципал прямо устанавливал полномочия агента на подписание арбитражного соглашения от его имени; австрийское законодательство также требует, чтобы указанное разрешение было выдано в письменной форме. В то время как во Франции, Италии и Германии письменное разрешение не является обязательным по закону. Данная теория была также принята американскими судами.

Доктрина «альтер-эго» или «снятия корпоративной вуали» была признана в международном арбитраже в целях предотвращения мошенничества или злоупотребления правом. Это исключительный механизм для избежания злоупотреблений со стороны компании, которая использует разделение юридического лица для совершения мошенничества или избежания ответственности, скрываясь за контролируемым юридическим лицом. Французские и американские суды в нескольких случаях «сняли» или «прокололи корпоративную вуаль», наметив тенденцию принимать данную теорию. Несмотря на это, обе юрисдикции подчеркивали необходимость применения данной доктрины только в исключительных случаях. Английские суды, с другой стороны, имели тенденцию избегать «снятия» или «прокалывания корпоративной вуали», если только корпоративная вуаль и самостоятель- ная правосубъектность не являются лишь обманом или фасадом. В Швейцарии и Германии суды подходят к данному вопросу с осторожностью и применяют данную доктрину лишь в исключительных обстоятельствах.

Включение путем ссылки признается арбитражными судами в той мере, в какой она подразумевает, что две стороны заключили договор, ссылаясь на другой договор, содержащий арбитражную оговорку. Как правило, для арбитров этого достаточно, когда ссылка на арбитражное соглашение является прямой, проблема же возникает, когда ссылка на документ не является прямой. Включение путем ссылки, как правило, применяется в строительных договорах и коносаментах. В прецедентном праве Соединенных Штатов это толковалось как случай, когда сторона, не подписавшая арбитражное соглашение, заключила иной договор с одной из сторон, в соответствии с которым она «приняла на себя все обязательства и привилегии, вытекающие из арбитражного соглашения», или когда арбитражная оговорка прямо включена в коносамент. Французская сторона придерживается весьма ограничительного подхода, требуя прямой ссылки. Английские суды также, как правило, имеют ограничительный подход [40, 529]. С другой стороны, позиция Швейцарии является более либеральной в плане признания действительности общей ссылки.

Термин «справедливый эстоппель» включает в себя два различных варианта доктрины. Первый вариант предусматривает, что сторона может быть лишена права утверждать, что отсутствие ее подписи в договоре препятствует приведению в исполнение арбитражной оговорки по этому договору, когда она последовательно указывала, что другие положения того же договора должны быть соблюдены в его пользу. Второй вариант справедливого эстоппеля используется для того, чтобы помешать подписавшим сторонам, которые пытаются обратиться в суд, отрицать существование арбитражной оговорки. Не подписавшая сторона не может быть лишена права отрицать существование такой оговорки.

Арбитражное соглашение может распространяться на стороннего бенефициара, что означает, что сторонний бенефициар может ссылаться на арбитражную оговорку, и она 
Распространение арбитражной оговорки на не подписавшие ее стороны: уроки сравнительного права

может быть использована против него. В прецедентах США и Великобритании указывается, что если третья сторона соглашается стать бенефициаром договора между другими сторонами, и этот договор содержит арбитражную оговорку, то эта третья сторона должна передать споры на такой арбитраж.

\section{ПРИМЕЧАНИЕ}

1 Работа выполнена при финансовой поддержке Гранта Президента РФ № НШ-2668-2020.6 «Национально-культурные и цифровые тренды социально-экономического и политико-правового развития Российской Федерации в XXI веке».

This work was financially supported by the Grant of the President of the Russian Federation No. HШ-2668-2020.6 "National-Cultural and Digital Trends in the Socio-Economic, Political and Legal Development of the Russian Federation in the $21^{\text {st }}$ Century".

\section{REFERENCES}

1. Acatos and Hutcheson Plc v Watson [1995] 1. Butterworth's Company Law Cases, 218.

2. Adams v Cape Industries plc [1990]. Ch 433.

3. Alcatel Business System v. Amkor Technologies et autres. Cour De Cassation, First Civil Chamber, 27 March 2007 (Petition No. 04-20.842).

4. Alfred McAlpine Construction Ltd. V. RMG Electrical (1994), Reported by R. Knowles. Development in Law Related to Arbitration. Arbitration, 1996, 188.

5. Ben Barret \& Son (Brickworth) Ltd. V. Henry Boot Management Ltd., 1995.

6. Bouriez v. Carnegie Mellon Univ, 359 F.3d, 292, 295 (3d Cir. 2004); accord Int'l Paper, 206 F.3d at 418.

7. Cass. le civ., June 26, 1990, Dreistern Werk v. Crouzier, 1991 REV. ARB. 291.

8. City of London v Sancheti [2008] EWCA Civ 1283 (21 November 2008).

9. Compagnie de Navigation et Transports SA v. MSC Mediterranean Shipping Co., Swiss Federal Court, January 16, 1995. ASA Bulletin, 503.

10. Dallah Real Estate \& Tourism Holding Co. v. Ministry of Religious Affairs, Government of Pakistan, United Kingdom Supreme Court, 3 November 2010, [2010] 3 W.L.R. 1472.

11. De Ment v. Nationwide Mutual Ins. Co. (S E 2d 239 Ct. App. 2001 797).

12. Ferrari, Franco \&Kröll, Stefan: Conflicts of Laws in International Arbitration. Sellier European Law Publishers, 2011, p. 160.
13. France, Cour de cassation, Société BomarOil N.V. v. Entreprise tunisienne d'activités pétroličres (ETAP) / 87-15.094, 11 October 1989.

14. Gouvernement du Pakistan-Ministčre des Affaires Religieuses v. Dallah Real Estate and Tourism Holding Company, Casos No. 09/28533, 09/28535y 09/28541, Appeal Court, Paris, 17 February 2011.

15. Hanotiau, Bernard: "Non-Signatories in International Arbitration: Lessons from Thirty Years of Case Law". Albert Jan van den Berg, ed., International Arbitration 2006: Back to Basics? (Alphen aan den Rijn (The Netherlands): Kluwer Law International, 2007), p. 351.

16. Inshakova A.O., Frolova E.E., Galkina M.V., Rusakova E.P. Development of Social Market Economy Under the Influence of Noneconomic Factors: Modeling and Regulation. International Journal of Sociology and Social Policy, 2020, pp. 1-11.

17. ICC Case No. 4131, Award 23 September 1982. Recueil de sentences arbitrales de la CCI 1974-1985, Kluwer, 1998, pp. $464 \mathrm{ff}$.

18. Int'l Paper Co. v. Schwabedissen Maschinen \& Anlagen GMBH, 206 F. 3d 411, 418 ( $4^{\text {th }}$ Cir. 2000).

19. ITSA v. Satcan \& BBVA. Spanish Supreme Court, 26 May 2005.

20. MS Dealer Serv. Corp. v. Franklin, 177 F.3d 942, 947 (11 ${ }^{\text {th }}$ Cir. 1999).

21. Oriental Com. \& Shipping Co. 609, F Supp. 28 in Born: International Commercial Arbitration in the United States, 1994, 1157.

22. Park, William. "Non-Signatories and International Arbitration” International Forum Selection. The Hague, Kluwer Law International, 1995, p. 581.

23. Peterson Farms Inc $v C \&$ \& Farming Ltd [2004] EWHC 121 (Comm) (04 February 2004).

24. Psichikon Compańia Naviera Panama v. Sté Sier et al., Court of Cassation (France) January 7, 1992. Rev. arb., 1992, 553.

25. Regent Seven Seas Cruise Inc v. Rolls Royce PLC et al. US District Court, Southern District of Florida, February 21, 2007. Yearbook Commercial Arbitration, 2008, 879.

26. Roussel-UclafV. G. D. Searle \& Co. Ltd. And G.D. Searle \& Co. [1978] 1 Lloyd's Rep. 225.

27. SARL Kosa France Holding et al. v. Rhodia Opérations et al, Court of Appeal, Paris, May 5, 2011. Rev. arb., 2011, p. 580.

28. Smith/Enron Cogeneration Ltd. V. Smith Cogeneration Int'l, 198 F.3d 88 (2d Cir. 1999).

29. Société Sponsor A.B. v. Ferdinand Louis Lestrade. C.A.Pau, 26 Nov. 1986, 1998. Rev. Arb., 153.

30. Sté Constructions Mécaniques de Normandie v. Sté Fagerdala Marine Systems et al., Court of Cassation, 26 October 2011. Rev. Arb., 2011, p. 1098.

31. Stephen Federico v. Chartered Mutual Assurance Association. District Court, Eastern District 


\section{МЕЖДУНАРОДНОЕ ПРАВО И СРАВНИТЕЛЬНОЕ ПРАВОВЕДЕНИЕ}

of Pennsylvania, June 13, 2001. Yearbook Commercial Arbitration, 2002, 635.

32. Suba France y otro v Pujol. Paris, 7 May 2009, $\mathrm{N}^{\circ} 08 / 02025$.

33. Sunkist Soft Drinks, Inc. v. Sunkist Growers, Inc., 10 F.3d 753 (11 $1^{\text {th }}$ Cir. 1993).

34. Switzerland, Tribunal Fédéral (Federal Tribunal) / Tradax Export SA v. Amoco Iran Oil Company, 7 February 1984.

35. Tareau v. Martin, Court of Cassation (France), July 16, (1992). Rev. arb., 1993, 611. Cited by RubinoSammartano, Mauro: Op Cit. p. 359.

36. Thomson-CSF S.A. v. American Arbitration Association, 64 F.3d 773 ( $2^{\text {nd }} C$ ir. 1995).
37. UNCITRAL Model Law on International Commercial Arbitration, Art. 7 (6). (United Nations documents A/40/17, annex I and A/61/17, annex I).

38. United States / 14 April 2005 / U.S. Court of Appeals, Second Circuit / Sarhank Group v. Oracle Corporation / 02-9383.

39. Woolfson v. Strathclyde Regional Council [1978] 2 EGLR 19 (HL), UKHL 5, 1978 SLT 159, 38 P\& CR521.

40. Zavyalova N.A., Frolova E.E., Bezbakh V.V., Rusakova E.P., Dudin M.N.BRICS Message from South Africa. Amazonia Investiga, 2020, vol. 9, no. 26, pp. 529-544.

\section{Information About the Authors}

Ekaterina P. Rusakova, Candidate of Sciences (Jurisprudence), Associate Professor, Department of Civil Law and Procedure and Private International Law, Peoples' Friendship University of Russia, Miklukho-Maklaya St, 6, 117198 Moscow, Russian Federation, rusakova-ep@rudn.ru, https://orcid.org 0000-0001-6488-0754

Edgar J. Young Dominguez, Postgraduate Student, Department of Civil Law and Procedure and Private International Law, Peoples' Friendship University of Russia, Miklukho-Maklaya St, 6, 117198 Moscow, Russian Federation, edgaryoung90@gmail.com, https://orcid.org/0000-0003-4527-2096

\section{Информация об авторах}

Екатерина Петровна Русакова, кандидат юридических наук, доцент кафедры гражданского права и процесса и международного частного права, Российский университет дружбы народов, ул. Миклухо-Маклая, 6, 117198 г. Москва, Российская Федерация, rusakova-ep@rudn.ru, https://orcid.org 0000-0001-6488-0754

Эдгар Хосуэ Йонг Домингес, аспирант кафедры гражданского права и процесса и международного частного права, Российский университет дружбы народов, ул. Миклухо-Маклая, 6, 117198 г. Москва, Российская Федерация, edgaryoung90@gmail.com, https://orcid.org/0000-0003-4527-2096 